\title{
CYTOTOXIC ACTIVITY OF THE FLAVONOID COMPOUNDS ISOLATED FROM Tetrameles nudliflora LEAVES
}

\author{
Megawati*, Akhmad Darmawan and Sofa Fajriah \\ Research Center for Chemistry, Indonesian Institute of Sciences, \\ Kawasan PUSPIPTEK Serpong, Kota Tangerang Selatan, 15314, Indonesia
}

\begin{abstract}
Tetrameles nudliflora is one of the endemic plants in Wallace region, especially in Mekongga Forest, Southeast Sulawesi, Indonesia. As part of our project in the field of natural drug discovery based on local bioresources, this study aimed to isolate secondary metabolite compounds from the ethyl acetate fractions of the leaves of T. nudiflora and evaluate their cytotoxic activities against breast carcinoma cancer lines, MCF-7. The methods used were various chromatography techniques such as vacuum column chromatography, gravitation column chromatography, thin layer chromatography, preparative thin layer chromatography, and re-crystallization using two different organic solvents. In the present study, two flavonoid compounds, kaempferol (1) and quercetin (2) were identified. The structures of 1-2 were determined using serial spectroscopic techniques, including mass spectrometry, oneand two-dimensional nuclear magnetic resonance. Moreover, using 3-(4,5-dimethylthiazol-2-yl)-2,5 diphenyl tetrazolium bromide (MTT) assay method, both compounds showed in vitro cytotoxic activity $\mathrm{IC}_{50}$ of 34.162 and $133.148 \mu \mathrm{g} \mathrm{mL}^{-1}$, respectively against MCF-7 cell lines.
\end{abstract}

Key words : Tetrameles nudiflora, flavonoid, kaempferol, quercetin, breast carcinoma, MCF-7 cancer cell lines

*Corresponding author;

Research Center for Chemistry, Indonesian Institute of Sciences,

Kawasan PUSPIPTEK Serpong, Kota Tangerang Selatan, 15314, Indonesia

Tel. +62-21-7560929

E-mail.megarafandi@gmail.com

\section{Introduction}

Indonesia, as one of the rich countries in the world for natural product resources, has already used many kind of plants and herbs species as traditional medicines. Many diseases such as cancer have been reported to be cured by traditional medicine system in Indonesia (WHO, 2014). The traditional medicine may offer minor side effect because it is free of synthetic chemicals. Nevertheless, further investigation is still required to determine the efficacy of the traditional medicinal plants in treating and curing cancer (Kamuhabwa et al., 2000; Ngoua-Meye-Misso et al., 2019). More than 3,000 traditional medicinal plants have been already identified in Indonesia (Zuhud, 2009). Among them, 2,518 species have been utilized, although only 262 species were used in traditional medicine system (Hariana, 2013; Buss, A. D et al.,2010). Tetrameles nudiflora is one of the members of Tetramelaceae family, Cucurbitales order, Angiosperms clade, and Plantae kingdom (Hanno et al., 2011). This plant is commonly found in Australia, Bangladesh, Bhutan, China, India, Laos, Malaysia, Myanmar, Sri Lanka, Thailand, Vietnam and Indonesia. In Indonesia, this plant is known as binong or winong and widely spread from Sumatra, Java, Sulawesi, Nusa Tenggara, and Papua (Priyadi et al., 2010; Sosef et al., 1998). Tetramelaceae is one of the tribes of flowering plants consisting of only two species, Octomeles sumatrana and Tetrameles nudiflora. T. nudiflora is a large tree with yellow flowers that grows up to $50 \mathrm{~m}$ high, and has a wide distribution in India, Sri Lanka, Myanmar, South China, Thailand, Indochina, Malaysia, North Australia, Laos and Vietnam (Priyadi et al., 2010). In Indonesia, these trees are widely distributed across Sumatra, Java, Sulawesi, Nusa Tenggara (Southeast Islands) and Papua (Banjarnahor et al., 2015). T. nudiflora was reported to have a potential biological inhibitory activity against $\alpha$ glucosidase as antidiabetic (Minarti et al., 2018). Kerala Forrest Research Institute also demonstrated that decoction from the bark of 
this plant has been used as a laxative, diuretic agent, and anti-rheumatic (Sasidharan et al., 1999). Moreover, the plant is also used to treat rheumatism, edema (Priyadi et al., 2010) and itching (Doley et al., 2014).

However, there are only few studies on secondary metabolites compounds of this plant, especially those from the leaves. Yet, our previous study indicated that $T$. nudiflora contains 20-epibryonolic acid and stigmasterol (Darmawan et al.2018; Salahudin et al., 2013). It led us to isolate, purify, and identify the further secondary metabolite compounds from the leaves of $T$. nudiflora and explore their biological activities. Therefore, the aim of this study was to explore the chemical constituents of the leaves of $T$. nudiflora using chromatography methods, to determine its chemical structure based on serial spectroscopic data, and to determine its potential as an anticancer against MCF-7 cell lines.

\section{Materials and Methods}

\section{Extraction and Isolation}

T. nudiflora leaves were collected from the Mekongga Forest, District of Kolaka, Southeast Sulawesi, Indonesia. The plant was determined in Herbarium Bogoriense, Research Centre for Biology, Indonesian Institute of Sciences (LIPI), Cibinong-Bogor, Indonesia.

T. nudiflora leaves were sorted from unwanted materials, washed with water and dried using blower oven cabinet at $50{ }^{\circ} \mathrm{C}$. Dried leaves were subjected to grinder (powder machine) to obtain dried and powdered leaves. After that, $1.28 \mathrm{~kg}$ of dried and powdered of $T$. nudiflora leaves were macerated in $10 \mathrm{~L}$ of methanol and evaporated using rotary evaporator to yield $185.30 \mathrm{~g}$ of methanol crude extract. Methanol soluble fraction (100 g) was subjected to column chromatography over silica gel and then was eluted with a gradient solvent system of n-hexane:EtOAc to obtain 30 fractions, namely F1-F30. Fraction 6 (F6) was further applied on Sephadex chromatography using methanol :dichloromethane $(1: 1)$ as eluent to give 10 sub-fractions (SF1-SF10). Compound 1 (15 mg) and 2 (20 mg) were isolated from sub-fractions 6.4 and 6.6 (SF 6.4 and SF-6.6, respectively).

\section{General and chemical structure analysis}

Chemical structure identification of compound $\mathbf{1}$ and $\mathbf{2}$ were performed using liquid chromatography-mass spectroscopy (LC-MS) and one- and two-dimensional (1D- and 2D) nuclear magnetic resonance (NMR). The 1Dand 2D-NMR spectra were recorded by JEOL JNM-ECA 500 spectrometer with $\mathrm{CD}_{3} \mathrm{OD}$ as a solvent and TMS as an internal standard. LCESI-MS were measured by the Mariner Biospectrometry-Finnigan instrument with methanol (Merck) as a solvent. Column chromatography was performed using silica gel (200-300 mesh, Kieselgel 60, E. Merck) as stationary phase.

\section{Cytotoxic assay}

The cytotoxic assay was conducted according to the method described (Fajriah et al., 2017; Megawati et al., 2016; Harneti et al., 2012). Firstly, MCF7 cells were incubated in the 96-well plates at an initial cell density of approximately $3 \times 10^{4}$ cells $\mathrm{cm}^{-3}$ for $24 \mathrm{~h}$. Various sample concentrations $(6.25,12.5,25$, 50, 100 and $200 \mu \mathrm{g} \mathrm{mL}^{-1}$ ) were then added. Samples were dissolved in dimethyl sulfoxide (DMSO) at the required concentration. Subsequent six desirable concentrations were prepared using phosphoric buffer solution (PBS) $\mathrm{pH}$ 7.30-7.65. Control wells received only DMSO. After $48 \mathrm{~h}$ incubation, assay was terminated by adding the dye reagent $3-(4,5-$ dimethylthiazol-2-yl)-2,5-diphenyl tetrazolium bromide (MTT), also named as thiazol blue. The incubation was then continued for another $4 \mathrm{~h}$, in which the MTT-stop solution containing SDS (sodium dodecyl sulphate) was added and another $24 \mathrm{~h}$ of incubation was conducted. Finally, optical density was read using a microplate reader at $550 \mathrm{~nm}$. $\mathrm{IC}_{50}$ values were taken from the plotted graph of percentage live cells compared to the control (\%) (received only PBS and DMSO), versus the tested concentration of the samples $(\mu \mathrm{m})$. The $\mathrm{IC}_{50}$ value is the concentration required for $50 \%$ growth inhibition. Each assay and analysis were run in triplicate and averaged.

\section{Results}

The compound 1 was isolated as a yellowishbrown crystal. The LC-ESI-MS $[\mathrm{M}+\mathrm{H}]^{+}$at $\mathrm{m} / z$ 287 and the ${ }^{1} \mathrm{H}-\mathrm{NMR}\left(500 \mathrm{MHz}\right.$ in $\mathrm{CD}_{3} \mathrm{OD}$ ) data showed that the compound $\mathbf{1}$ has six aromatic protons at $\delta_{\mathrm{H}} 6.18,6.39,6.90(2 \mathrm{H})$ and $8.09(2 \mathrm{H})$. 
Table 1. ${ }^{1} \mathrm{H}$ - and ${ }^{13} \mathrm{C}-\mathrm{NMR}$ of compound $\mathbf{1}$ and Kaempferol

\begin{tabular}{|l|l|l|l|l|}
\hline \multirow{2}{*}{ No. } & \multicolumn{2}{|l|}{ Compound 1 } & \multicolumn{2}{l|}{ Kaempferol (Xiao et al., 2006) } \\
\cline { 2 - 5 } & $\begin{array}{l}\delta_{\mathrm{H}} \mathrm{ppm}(\Sigma \mathrm{H}, \\
\text { mult. } J \mathrm{~Hz})\end{array}$ & $\delta \mathrm{c} \mathrm{ppm}$ & $\begin{array}{l}\delta_{\mathrm{H}} \mathrm{ppm}(\Sigma \mathrm{H}, \text { mult. } J \\
\mathrm{Hz})\end{array}$ & $\delta \mathrm{c} \mathrm{ppm}$ \\
\hline 2 & - & 148.1 & - & 146.9 \\
\hline 3 & - & 137.2 & - & 136.5 \\
\hline 4 & - & 177.6 & - & 176.5 \\
\hline $4 \mathrm{a}$ & - & 104.5 & - & 103.9 \\
\hline 5 & - & 158.4 & - & 157.7 \\
\hline 6 & $\begin{array}{l}6.18(1 \mathrm{H}, d, J= \\
1.95)\end{array}$ & 94.6 & $6.27(1 \mathrm{H}, d, J=2.0)$ & 98.9 \\
\hline 7 & - & 166.0 & - & 165.0 \\
\hline 8 & $\begin{array}{l}6.39(1 \mathrm{H}, d, J= \\
1.95)\end{array}$ & 99.6 & $6.54(1 \mathrm{H}, d, J=2.0)$ & 94.3 \\
\hline $8 \mathrm{a}$ & - & 162.6 & - & 160.1 \\
\hline $1^{\prime}$ & - & 123.8 & - & 123.1 \\
\hline & & & & 130.3 \\
\hline $2^{\prime} / 6^{\prime}$ & $\begin{array}{l}8.09(2 \mathrm{H}, d, J= \\
9.08)\end{array}$ & $130.8(2 \mathrm{C})$ & $8.16(2 \mathrm{H}, d, J=8.8)$. & \\
\hline $3^{\prime} / 5^{\prime}$ & $\begin{array}{l}6.91(2 \mathrm{H}, d, J= \\
9.08)\end{array}$ & $116.4(2 \mathrm{C})$ & $7.03(2 \mathrm{H}, d, J=8.8)$ & 116.1 \\
\hline $4^{\prime}$ & - & 160.7 & & 161.9 \\
\hline
\end{tabular}

The compound $\mathbf{2}$ was isolated as a yellowishbrown crystal. The LC-ESI-MS $[\mathrm{M}+\mathrm{H}]^{+}$at $\mathrm{m} / z$ 303.04 and the ${ }^{1} \mathrm{H}-\mathrm{NMR}\left(500 \mathrm{MHz}\right.$, in $\left.\mathrm{CD}_{3} \mathrm{OD}\right)$ data showed that the compound $\mathbf{2}$ has five aromatic protons at $\delta_{\mathrm{H}} 6.18(1 \mathrm{H}, d, J=1.95 \mathrm{~Hz}$, $\mathrm{H}-9), 6.39(1 \mathrm{H}, d, J=1.95 \mathrm{~Hz}, \mathrm{H}-1), 6.88(1 \mathrm{H}$, $d, J=8.43 \mathrm{~Hz}, \mathrm{H}-5$ ') $7.63(1 \mathrm{H}, d d, J=1.95 \&$ $8.43 \mathrm{~Hz}, \mathrm{H}-6$ '), and $7.73(1 \mathrm{H}, d, J=1.95 \mathrm{~Hz}, \mathrm{H}-$ 2').

Tabel 2. ${ }^{1} \mathrm{H}$ - and ${ }^{13} \mathrm{C}$-NMR of the compound 2 and quercetin

\begin{tabular}{|c|c|c|c|c|}
\hline \multirow[b]{2}{*}{ No. } & \multicolumn{2}{|l|}{ Compound 2} & \multicolumn{2}{|c|}{$\begin{array}{c}\text { Quercetin } \\
\text { (Xiao et al., 2006) }\end{array}$} \\
\hline & $\begin{array}{ll}\delta_{\mathrm{H}} & \text { ppm } \\
(\Sigma \mathrm{H}, & \text { mult. } \\
J \mathrm{~Hz}) & \end{array}$ & $\delta_{\mathrm{C}} \mathrm{ppm}$ & $\begin{array}{l}\delta_{\mathrm{H}} \operatorname{ppm}(\Sigma \mathrm{H}, \\
\text { mult. } J \mathrm{~Hz})\end{array}$ & $\delta_{\mathrm{C}} \mathrm{ppm}$ \\
\hline 1 & - & - & - & - \\
\hline 2 & 148.0 & - & 155.3 & - \\
\hline 3 & 137.3 & - & 133.0 & - \\
\hline 4 & 177.6 & - & 177.6 & - \\
\hline 5 & 104.6 & - & 103.7 & - \\
\hline 6 & 158.3 & - & 160.8 & - \\
\hline 7 & 94.5 & $6.39(d, 1.95)$ & 93.4 & $6.53(d)$ \\
\hline 8 & 165.7 & - & 163.4 & \\
\hline 9 & 99.3 & $6.18(d, 1.95)$ & 98.4 & $\begin{array}{l}6.27 \\
(d) \\
\end{array}$ \\
\hline 10 & 162.6 & - & 156.1 & \\
\hline 1 ' & 124.2 & - & 121.0 & \\
\hline 2 ' & 116.0 & $7.73(d, 1.95)$ & 115.7 & $\begin{array}{l}7.70 \\
(d d) \\
\end{array}$ \\
\hline 3 ' & 146.3 & - & 144.6 & \\
\hline 4 ' & 148.9 & - & 148.2 & \\
\hline 5 & 116.3 & $6.88(d, 8.43)$ & 115.2 & $6.99(d)$ \\
\hline 6 ' & 121.7 & $\begin{array}{l}7.63(d d, 1.95 \\
\& 8.43)\end{array}$ & 122.1 & $\begin{array}{l}7.81(d \\
d)\end{array}$ \\
\hline
\end{tabular}

Examination of the cytotoxicity activity of the compound $\mathbf{1}$ and $\mathbf{2}$ against breast carcinoma (MCF-7) cells lines showing that kaempferol and quercetin compounds were active as anticancer. The $\mathrm{IC}_{50}$ values of those compounds were 34.162 and $133.148 \mu \mathrm{g} \mathrm{mL} \mathrm{m}^{-1}$, respectively.

\section{Discussion}

The constant coupling values, it can be seen that $\delta_{\mathrm{H}} 6.18$ was correlated with $\delta_{\mathrm{H}} 6.39$ in meta position. Meanwhile, $\delta_{\mathrm{H}} 6.90(2 \mathrm{H})$ showed an ortho correlation with $\delta_{\mathrm{H}} 8.09(2 \mathrm{H})$. Presence of the $\mathrm{AB}$ pattern of aromatic ring proton system of the A ring (the first aromatic ring in flavonoid chemical structure) was shown by two proton signals at $\delta_{\mathrm{H}} 6.18$ and 6.39 (Fig. 1a). Moreover, the $A_{2} B_{2}$ pattern seen in the $B$ ring suggesting that the $\mathrm{B}$ ring has two symmetric proton peaks at $\delta_{\mathrm{H}} 6.90$ and 8.09 , with an ortho correlation (Fig. 1b). The ${ }^{13} \mathrm{C}-\mathrm{NMR}\left(125 \mathrm{MHz}\right.$, in $\left.\mathrm{CD}_{3} \mathrm{OD}\right)$ spectrum showed the presence of six artificial methyl $(\mathrm{CH})$ appearing at $\delta_{\mathrm{C}} 94.6,99.5,116.4$ (2C), and $130.8(2 \mathrm{C})$, with eight quaternary carbon at $\delta_{\mathrm{C}} 104.5,123.8,137.2,148.1,158.4$, $160.7,162.6$, and 166.0 , and a carbonyl group at $\delta_{\mathrm{C}} 177.5$.
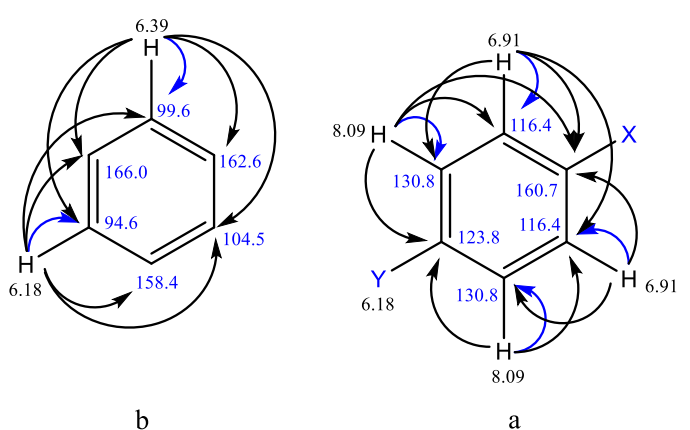

Figure 1. Pattern of proton system of aromatic ring at the $\mathrm{A}$ and $\mathrm{B}$ rings of compound 1

Based on ${ }^{1} \mathrm{H}-,{ }^{13} \mathrm{C}-\mathrm{NMR}$ and LC-ESI-MS data, supported by HMQC and HMBC analysis (Fig. 2), the LC-ESI-MS data and the comparison with appropriate reference (Table $1)$, it can be concluded that compound $\mathbf{1}$ is kaempferol (Xiao et al., 2006) (Fig. 3). 


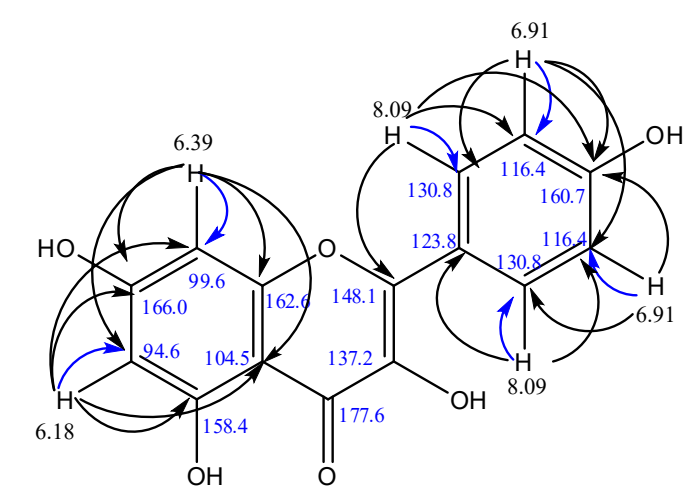

Figure 2. HMQC and HMBC- correlations of compound 1<smiles>O=c1c(O)c(-c2ccccc2)oc2ccc(O)c(O)c12</smiles>

Figure 3. Chemical structure of kaempferol (Xiao et al., 2006)

The coupling constant data of ${ }^{1} \mathrm{H}-\mathrm{NMR}$ signals of the compound $\mathbf{2}$ showed that the proton signal at $\delta_{\mathrm{H}} 6.18$ correlated with the proton signal at $\delta_{\mathrm{H}} 6.39$ in meta position. A proton signal at $\delta_{\mathrm{H}} 7.63$ correlated to $\delta_{\mathrm{H}} 7.73$ and 6.88 in ortho and meta positions, respectively (Fig. 4).

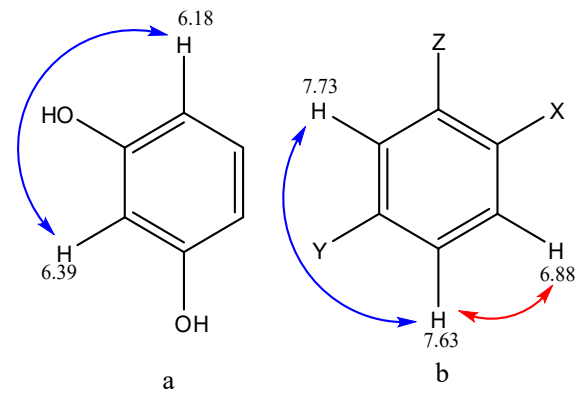

Figure 4. The proton pattern of the A and $\mathrm{B}$ rings of the compound 2

Two proton peaks at $6.18 \mathrm{ppm}(1 \mathrm{H}, d, J=$ $1.95 \mathrm{~Hz})$ and $6.39 \mathrm{ppm}(1 \mathrm{H}, d, J=1.95 \mathrm{~Hz})$ in the first ring (the $\mathrm{A}$ ring) showed the $\mathrm{AB}$ pattern of aromatic ring proton system (Fig. 4a), and the second ring (the $\mathrm{B}$ ring) showed the $\mathrm{AXB}$ pattern, indicated that the second aromatic ring has three-substituted protons at $\delta_{\mathrm{H}} 7.63(1 \mathrm{H}, d d$, $J=1.95 \& 8.43 \mathrm{~Hz}), 6.88 \mathrm{ppm}(1 \mathrm{H}, d, J=8.43$ $\mathrm{Hz}$, ), and $7.73 \mathrm{ppm}(1 \mathrm{H}, d, J=1.95 \mathrm{~Hz})$ (Fig. 4b). ${ }^{13} \mathrm{C}-\mathrm{NMR}\left(125 \mathrm{MHz}\right.$, in $\left.\mathrm{CD}_{3} \mathrm{OD}\right)$ data showed the presence of five artificial methyl $(\mathrm{CH})$ groups appearing at $\delta_{\mathrm{C}} 94.5(\mathrm{C}-6), 99.3(\mathrm{C}-$ 8), 116.0(C-2'), 116.3 (C-5'), and 121.7 (C-6'), with 10 different signals of quaternary carbon at $\delta_{\mathrm{C}} 104.6(\mathrm{C}-4 \mathrm{a}), 124.2$ (C-1'), 137.3 (C-3), 146.3 (C-3'), 148.0 (C-2), 148.9 (C-4'), 158.3 (C-5), 162.6 (C-8a), 165.7 (C-7), and 177.6 $(\mathrm{C}=\mathrm{O}, \mathrm{C}-4)$. In addition, the chemical shift at $\delta_{\mathrm{C}}$ $177.5 \mathrm{ppm}$ indicated the presence of a carbonyl group. Based on the NMR data above $\left({ }^{1} \mathrm{H}-\right.$ and ${ }^{13} \mathrm{C}$-NMR), supported by HMQC and HMBC data (Fig. 5), the LC-ESI-MS data, and the comparison with appropriate reference (Table $2)$, it can be concluded that compound $\mathbf{2}$ is quercetin (Xiao et al., 2006) (Fig. 6).

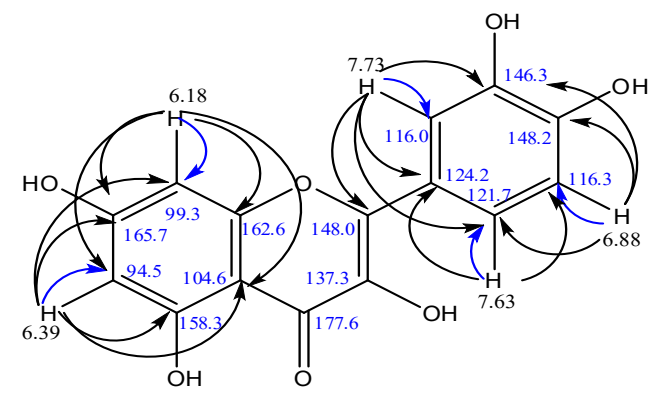

Figure 5. HMQC and HMBC correlations of compound 2<smiles>O=c1c(O)c(-c2ccc(O)c(O)c2)oc2cc(O)cc(O)c12</smiles>

Figure 6. The chemical structure of quercetin (Xiao et al., 2006)

The cytotoxicity activity of the compound 1 (kaemferol) and 2 (quercetin) against breast carcinoma (MCF-7) cells, a kaempferol can cause apoptosis in MCF-7 cells through the introduction of the intrinsic caspase cascade and through the down-regulation of the Polo-likekinase-1 (PLK-1), so that kaempferol has higher activity than quercetin (Stapel et al., 2013). 


\section{Conclusion}

Isolation and purification of kaempferol and quercetin from ethyl acetate fraction 6 (F-6) of leavers of $T$. nudiflora using column chromatography method have been done successfully. The chemical structure elucidation was determined based on the spectroscopic data analysis (1D-, 2D-NMR and LC-ESI-MS) together with the appropriate reference comparison. Kaemferol and quercetin compounds showed high cytotoxicity activity against breast carcinoma (MCF-7) cells line with $\mathrm{IC}_{50}$ values of 34.162 and $133.148 \mu \mathrm{g} \mathrm{mL}$ ${ }^{1}$, respectively.

\section{Acknowledgements}

Authors are thankful to Prof. Dr. Sci. Muhammad Hanafi for his beneficial support, discussion and collaboration, as well as to Mrs. Puspa Dewi N. Lotulung, M.Eng for the mass spectroscopy measurement and interesting discussion. Moreover, we also would like to thank to Indonesian Institute of Sciences (LIPI) for funding our research project through LIPI Competitive Research Grant 2012-2014.

\section{References}

Banjarnahor, S. D. S., Dewijanti, I. D., Angelina, M., Megawati, \& Fajriah, S. (2005). Toxicological evaluation of Tetrameles nudiflora methanolic extract. The Journal of Tropical Life Science, 5(1): 53-59.

Buss, A. D and Butler, M. S. (2010). Natural Product Chemistry for Drug Discovery. Royal Society of Chemistry, pp 20. Chapter 1.

Bhabajit, D., Gajurel, P. R., Rethy, P., \& Buragohain, R. (2014). Uses of trees as medicine by the ethnic communities of Arunachal Pradesh, India Journal of Medicinal Plant Research, 8(24): 857-863.

Darmawan, A., Fajriah, S., Megawati, \& Puspa Dewi Lotulung, P. D. (2018). Isolation of 20epibryonolic acid from Tetrameles nudiflora leaves. Research Journal of Chemistry and Environment, 22: 87-90.

Doley B., Gajurel P.R., Rethy P., and Buragohain R. (2014). Uses of trees as medicine by the ethnic communities of Arunachal Pradesh, India. Journal of Medicinal Plant Research. 8(24): 857863.

Fajriah S., Darmawan, A., Megawati, Sumi Hudiyono, S., Kosela, S., \& Hanafi, M. (2017). New cytotoxic compounds from Myristica fatua Houtt leaves against MCF-7 cell lines. Phytochemistry Letters, 20: 36-39.
Hariana, A. (2013). Tumbuhan obat dan khasiatnya. Penebar Swadaya. Jakarta.

Harneti, D., Tjokronegoro, R., Safari, A., Supratman, U., Loong, X., Mukhtar, M. R., Mohamad, K., Awang, $\mathrm{K}$ and Hayashi, $\mathrm{H}$. (2012). Cytotoxic triterpenoid from the bark of Aglaia smithii (Meliaceae). Phytochemistry Letters. 5(3): 496-499.

Hanno Schaefer \& Susanne S. (2011). Renner Phylogenetic relationships in the order Cucurbitales and a new classification of the gourd family (Cucurbitaceae). Taxon 60 (1): 122-138.

Kamuhabwa A., Charles, N \& Peterde, Witte. (2000). Cytotoxicity of some medicinal plant extracts used in Tanzanian traditional medicine. Journal of Ethnopharmacology, 70(2): 143-149.

Megawati, Hanafi, M., Saepudin, E \& Fajriah, S. (2016). Isolation, identification and cytotoxic activity of scopoletin from leaf of Macaranga hispida (Bume) Mull. Arg. Jurnal Ilmu Kefarmasian Indonesia, 14(1): 42-46.

Minarti, M., Mulyani, H., Megawati, Meilawati, L., Fajriah, S, and Widiyarti, G. (2018). Isolation of stigmasterol and 20-epibryonolic acid from Tetrameles nudiflora stem bark. In Proceedings of the 4th International Symposium on Applied Chemistry,AIP Conference Proceedings 2024 (pp 020006). https://doi.org/10.1063/1.5064292.

Ngoua-Meye-Misso, R.-L., Sima-Obiang, C., Ndong, J. D. L. C., Guy-Roger, N. -A., Ondo, J. P., Abessolo, F., \& Obame-.Engonga, L.-C. (2019). Medicinal plants used in management of cancer and other related diseases in Woleu-Ntem province, Gabon European. Journal of Integrative Medicine. V 29: 100924.

Priyadi, H., Takao, Rahmawati, Supriyanto., Nursal, I., \& Rahman. (2010). Five hundred plant species in Gunung Halimun Salak National Park, West Java: A checklist including Sundanese names, distribution, and use. Center for International Forestry Research.; p. 16. https://doi.org/ 10.13140/2.1.2823.5845

Salahuddin., Fajriah, S., Megawati \& Darmawan, A. (2013). Isolasi dan identifikasi senyawa sterol dari fraksi heksan daun Tetrameles nudiflora. In Prosiding Seminar Nasional XXII" Kimia dalam Industri dan Lingkungan" Yogyakarta ISSN 0854-4778 . (pp 105-110).

Sasidharan, N., Bhasha, S. C and Renuka, C. (1999). Botanical Studies In The Medicinal Plant Conservation Areas In Kerala. KFRI Research Report. pp 75.

Schaefer, H. \& Renner, S. S. (2011). Renner phylogenetic relationships in the order Cucurbitales and a new classification of the gourd family (Cucurbitaceae). Taxon, 60 (1): 122-138.

Sosef, M. S. M., Hong, L. T., \& Prawirohatmodjo, S. (1998). Timber Trees: Lesser-Known Timbers, 
Backhuys Publishers,Leiden. Plant Resources of South-ast Asia. No 5(3).

Stapel, J., Oppermann C., Richter D. U., Ruth W \& Briese V. (2013). Polyphenol compounds with anti-carcinogenic qualities: Effects of quercetin (flavonol), chrysin (flavon), kaempferol (flavanol), naringenin (flavanon) and hesperidin (flavanoid) on in vitro breast cancer.Academic Journal, Vol.7(29), pp. 2187-2196 https:// doi.org/10.5897/JMPR12.5126
World Health Organization. 2014. Cancer Country Profiles. https://www.who.int/cancer/countryprofiles).access 06 january 2020.

Xiao, Z. P., Wu, H. K., Wu, T., Shi, H., Hang, B., \& Aisa, H. A. (2006). Kaemferol and quercetin flavonoids from Rosa rugose. Journal Chemistry of Natural Compounds, 42,(6):736-737 https://doi.org/10.1007/s10600-006-0267-3

Zuhud, E. A. M. (2009). Potensi hutan tropika Indonesia sebagai penyangga bahan obat alam untuk kesehatan bangsa. Jurnal Bahan Alam Indonesia, 6 (6): 227-232. 